\title{
Ozone air quality during the 2008 Beijing Olympics: effectiveness of emission restrictions
}

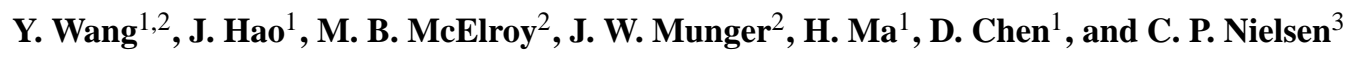 \\ ${ }^{1}$ Department of Environmental Science and Engineering and State Key Joint Laboratory of Environment Simulation and \\ Pollution, Tsinghua University, Beijing, China \\ ${ }^{2}$ Department of Earth and Planetary Sciences and School of Engineering and Applied Sciences, Harvard University, \\ Cambridge, Massachusetts, USA \\ ${ }^{3}$ Harvard China Project and School of Engineering and Applied Sciences, Harvard University, Cambridge, \\ Massachusetts, USA
}

Received: 7 April 2009 - Published in Atmos. Chem. Phys. Discuss.: 20 April 2009

Revised: 11 July 2009 - Accepted: 20 July 2009 - Published: 29 July 2009

\begin{abstract}
A series of aggressive measures was launched by the Chinese government to reduce pollutant emissions from Beijing and surrounding areas during the Olympic Games. Observations at Miyun, a rural site $100 \mathrm{~km}$ downwind of the Beijing urban center, show significant decreases in concentrations of $\mathrm{O}_{3}, \mathrm{CO}, \mathrm{NO}_{\mathrm{y}}$, and $\mathrm{SO}_{2}$ during August 2008, relative to August 2006-2007. The mean daytime mixing ratio of $\mathrm{O}_{3}$ was lower by about $15 \mathrm{ppbv}$, reduced to $50 \mathrm{ppbv}$, in August 2008. The relative reductions in daytime $\mathrm{SO}_{2}, \mathrm{CO}$, and $\mathrm{NO}_{\mathrm{y}}$ were $61 \%, 25 \%$, and $21 \%$, respectively. Changes in $\mathrm{SO}_{2}$ and in species correlations from 2007 to 2008 indicate that emissions of $\mathrm{SO}_{2}, \mathrm{CO}$, and $\mathrm{NO}_{\mathrm{x}}$ were reduced at least by $60 \%, 32 \%$, and $36 \%$, respectively, during the Olympics. Analysis of meteorological conditions and interpretation of observations using a chemical transport model suggest that although the day-to-day variability in ozone is driven mostly by meteorology, the reduction in emissions of ozone precursors associated with the Olympic Games had a significant contribution to the observed decrease in $\mathrm{O}_{3}$ during $\mathrm{Au}$ gust 2008, accounting for $80 \%$ of the $\mathrm{O}_{3}$ reduction for the month as a whole and $45 \%$ during the Olympics Period (824 August). The model predicts that emission restrictions such as those implemented during the Olympics can affect $\mathrm{O}_{3}$ far beyond the Beijing urban area, resulting in reductions in boundary layer $\mathrm{O}_{3}$ of 2-10 ppbv over a large region of the North China Plain and Northeastern China.
\end{abstract}

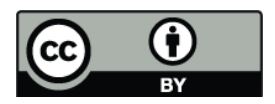

Correspondence to: Y. Wang (yxw@tsinghua.edu.cn)

\section{Introduction}

Ozone is produced in the troposphere by photochemical oxidation of carbon monoxide (CO) and volatile organic carbon (VOCs), initiated by reaction with $\mathrm{OH}$ in the presence of $\mathrm{NO}_{\mathrm{x}}$. In surface air, ozone has an adverse impact on both humans and vegetation (NRC, 1991). Due to its relatively long lifetime, it can be transported over long distances from source regions, making ozone pollution an issue of global concern.

China's rapid economic growth in recent years has resulted in large increases in pollutant emissions (Zhang et al., 2007; Ohara et al., 2007) with important implications for ozone on both regional and global scales. Beijing, China's capital, is one of the world's largest metropolises with a population of over 15 million with a vehicle fleet of more than 3 million. Beijing's air quality problems were characterized historically by high concentrations of particulate matter and sulfur dioxide (Hao and Wang, 2005). In recent years, due to a rapid increase in vehicular emissions, ozone pollution has drawn increasing attention in Beijing (Hao and Wang, 2005; Wang et al., 2006), especially in the period leading up to the Summer Olympic Games (August 2008) (http://www. nytimes.com/2007/12/29/world/asia/29china.html). Formulating a successful strategy to address $\mathrm{O}_{3}$ pollution poses a difficult challenge as a consequence not only for Beijing but also for other regions of the developed and developing world.

To improve air quality during the Olympics (8-24 August 2008) and the Paralympics (9-17 September 2008), the Chinese government implemented a series of aggressive measures to reduce pollutant emissions in Beijing and surrounding areas for more than two months during the time periods of the Olympics and the Paralympics. From 1 July

Published by Copernicus Publications on behalf of the European Geosciences Union. 
to 20 September 2008, all vehicles that failed to meet the European No. I standards for exhaust emissions (including light-duty and heavy-duty trucks and inefficient personal vehicles) were banned from Beijing's roads. Mandatory restrictions were implemented from 20 July to 20 September for personal vehicles, allowing them on roads only on alternate days depending on license plate numbers (odd-numbered vehicles on odd-numbered days and even-numbered vehicles on even-numbered days). As a result, traffic flows in Beijing urban areas were found to have declined by $22 \%$ during the Olympics (Y. Wu, personal communications). In addition to traffic emission controls, other area and point sources in Beijing were placed under strict control during the same period. Power plants in Beijing were required to reduce their emissions by $30 \%$ from their levels in June when they had already met the Chinese emission standard. Several heavilypolluting factories were ordered to reduce their operating capacities or to completely shut down during the Games. All construction activities were placed on hold. Since it has been shown that Beijing's air quality problems also have regional causes (Streets et al., 2007; L. Wang et al., 2008), emission controls on large industrial sources were also applied in surrounding provinces (e.g. Inner Mongolia, Shanxi, Hebei, Shandong) and in the city of Tianjin. Traffic restrictions similar to Beijing's were instituted in Tianjin during the Olympics Games.

As a result of these initiatives, one would expect to see significant decreases in emissions of ozone precursors $(\mathrm{CO}$, $\mathrm{NO}_{\mathrm{x}}$, and VOCs) and other key pollutants $\left(\mathrm{SO}_{2}\right.$ and particulates, for example) in Beijing. Wang et al. (2007) and Cheng et al. (2008) demonstrated that the four-day traffic restrictions in Beijing during the Sino-African Summit in early November 2006 resulted in significant temporary reductions in concentrations of $\mathrm{NO}_{\mathrm{x}}$ and particulates in the city. Compared with the Sino-African Summit, the emission reductions during the Olympic Games were more aggressive, affecting more than the transportation sector and lasting much longer. The effect on ozone is an important research question as the dependence of $\mathrm{O}_{3}$ production on $\mathrm{NO}_{\mathrm{x}}$ and VOCs is significantly different between the so-called $\mathrm{NO}_{\mathrm{x}}$-limited regime and the hydrocarbon-limited regimes (Sillman et al., 1990). Many previous studies investigated the nonlinear $\mathrm{O}_{3}$ chemistry and challenges of combating $\mathrm{O}_{3}$ pollution in cities of developed countries (Sillman et al., 1995; Murphy et al., 2006, 2007; Harley et al., 2005; Trainer et al., 2000). Compared with these studies, basic scientific understanding about surface $\mathrm{O}_{3}$ and precursor emissions in Chinese cities has been minimal. For example, examining the day-of-week variations of $\mathrm{O}_{3}$ provides a useful methodology to improve understanding of nonlinear ozone chemistry for many western cities and downwind regions (Murphy et al., 2006, 2007). However, no such "weekend" effect has been observed for precursor emissions in China (Beirle et al., 2003), likely due to different emission patterns related to social-economic factors in China. This suggests that it is essential to study in situ observations of important atmospheric species in China.

The present study will focus on the impact of the Olympics emission restrictions on air quality, particularly on surface ozone in the summertime, through analysis of surface observations at a rural site downwind of Beijing. Without a network of multiple observational sites over different parts of Beijing urban area, this study employs long-term, continuous measurements of $\mathrm{O}_{3}, \mathrm{CO}, \mathrm{NO}_{\mathrm{y}}$, and $\mathrm{SO}_{2}$ at a suburban/rural site (Wang et al., 2008b) located directly downwind of the Beijing urban area during summer months. Species correlations at the site will be used to infer "top-down" constraints on the magnitude of emission restrictions during the Olympics. The nested-grid version of the GEOS-Chem global chemical transport model (Wang et al., 2004a; Chen et al., 2009) will be employed to interpret the observations and to evaluate the reductions in emissions during the Olympics.

The emission restrictions associated with the Olympic Games offer an invaluable opportunity to test our understanding of the chemistry and dynamics affecting ozone and its precursors in a major Chinese urban environment. The ability of chemical transport models (CTMs) to reproduce changes in tropospheric ozone arising in response to these emission changes provides an important test of these models.

We begin by introducing the Miyun site and the nestedgrid GEOS-Chem model. The paper is organized then in two parts. The first is devoted to observational results. Trace gas concentrations and meteorological conditions measured at the Miyun site in August 2008 are compared with observations for Augusts of the two preceding years, demonstrating significant decreases in $\mathrm{O}_{3}, \mathrm{CO}, \mathrm{NO}_{\mathrm{y}}$, and $\mathrm{SO}_{2}$ during $\mathrm{Au}-$ gust 2008. We show that the reduction in pollution levels during the Olympics, far exceeding the magnitude attributed to year-to-year changes in meteorology, reflects most a response to the emission reductions. Using species concentrations and their correlations observed at Miyun, quantitative estimates are derived for the magnitude of emission reductions for $\mathrm{SO}_{2}, \mathrm{CO}$, and $\mathrm{NO}_{\mathrm{x}}$ during the Olympics employing a "top-down" approach independent of any modeling or bottom-up information. The latter part of the paper focuses on a model-based analysis. The extent to which the "topdown" estimates of emission reductions improves the performance of the model in simulating the observations at Miyun provides an independent evaluation of the observational analysis conducted in the first part of the paper. Model sensitivity analysis is used to differentiate quantitatively between meteorology- and emission-driven changes in ozone during the Olympics. The impact of the emission reductions of $\mathrm{O}_{3}$ at a regional scale is also predicted by the model. Concluding remarks are presented in Sect. 5. 


\section{Observations and model}

\subsection{Surface observations}

The Miyun site $\left(40^{\circ} 29^{\prime} \mathrm{N}, 116^{\circ} 46.45^{\prime} \mathrm{E}\right)$ is located at an elevation of about $152 \mathrm{~m}$ in Miyun County (population of about 420000 ), about $100 \mathrm{~km}$ northeast of the Beijing urban area. The terrain to the south of the site falls off gradually to about $90 \mathrm{~m}$ in a region characterized by a mix of agriculture and small villages. Mountains rise steeply to the north. There are no big point sources between the Beijing urban area and the site, nor close to the site in other directions. A map of the Beijing-Miyun region was shown in Fig. 1 of Wang et al. (2008b) and is not reproduced here. The station was established through a collaboration between the Harvard China Project and Tsinghua University. The measurements began in November 2004 and include continuous observations of $\mathrm{O}_{3}, \mathrm{CO}, \mathrm{CO}_{2}$, together with basic meteorological data (temperature, relative humidity, and wind speed and direction). Additional instruments measuring $\mathrm{NO}, \mathrm{NO}_{\mathrm{y}}$, and $\mathrm{SO}_{2}$ were added in 2006, with data collection for these species initiated in early 2007. The present study focuses on measurements of $\mathrm{O}_{3}, \mathrm{CO}, \mathrm{NO}_{\mathrm{y}}$, and $\mathrm{SO}_{2}$ for July, August, and September (JAS) 2008 when the emission restrictions were in place. Mixing ratios of these species measured for the same period in 2006 and 2007 are used for comparison. Measurements in summer 2005 had many gaps due to instrumental problems and are not included for comparison. Figure 1 shows afternoon wind directions recorded at the Miyun site in August 2006-2008. The prevailing SSW-SW-S winds suggest that the Miyun site is located directly downwind of the Beijing urban area in summer. Miyun observations are representative therefore of plume conditions of Beijing urban pollution in summer.

The $\mathrm{O}_{3}$ and $\mathrm{CO}$ instruments and the site details are discussed in Wang et al. (2008b). The $\mathrm{NO}_{\mathrm{y}}$ and $\mathrm{SO}_{2}$ instruments are outlined here. The $\mathrm{NO}_{\mathrm{y}}$ mixing ratio is measured by the chemiluminescence method (Thermo Environmental Instruments $42 \mathrm{C}-\mathrm{Y}$ ). Sample air is drawn first into an inlet $6 \mathrm{~m}$ above the ground and then split into two parallel channels. The $\mathrm{NO}_{\mathrm{y}}$ channel uses a heated molybdenum converter to reduce all forms of $\mathrm{NO}_{\mathrm{y}}$ to NO. The catalyst is preceded by as short a section of Teflon tubing as practical to minimize loss of $\mathrm{HNO}_{3}$ and other surface active compounds on tubing walls before they reach the catalyst. The instrument response and catalyst efficiency are calibrated every $6 \mathrm{~h}$ by introducing NIST traceable standard NO and n-propyl nitrate into the sample air in sequence. The $\mathrm{SO}_{2}$ mixing ratio is measured by a pulsed fluorescence method (Thermo Environmental Instrument 43CTL). Sample air is drawn from the same inlet as $\mathrm{CO}$ and $\mathrm{O}_{3}$, and a mass flow controller upstream of the instrument maintains constant flow in the system. The instrument zero is determined every $2 \mathrm{~h}$ by passing sample air into a denuder coated with sodium carbonate. A calibration sequence is implemented every $6 \mathrm{~h}$ by introducing NIST
Miyun Afternoon Wind Directions in August

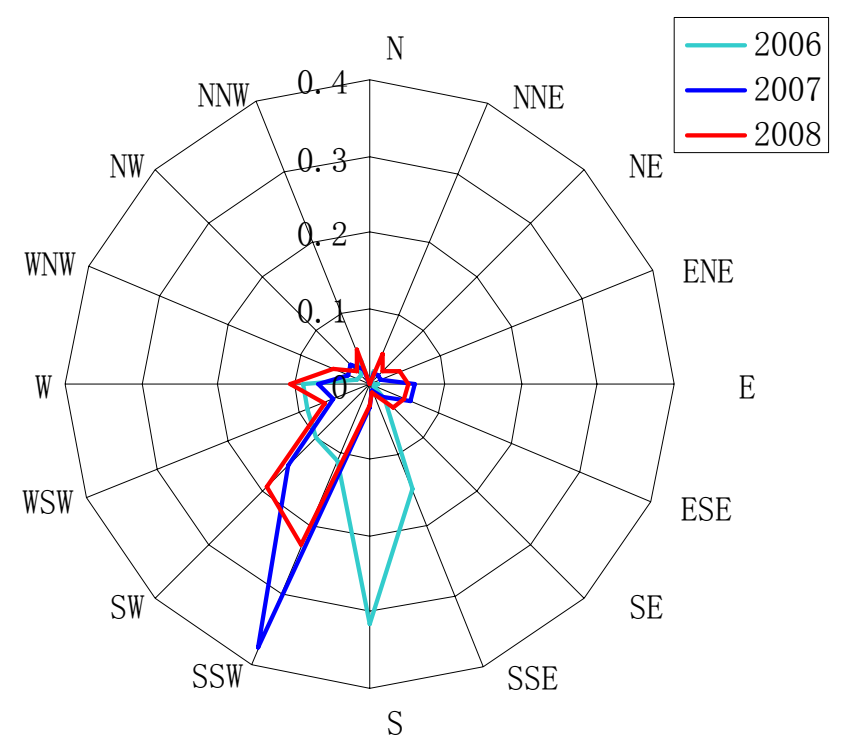

Fig. 1. Wind roses of afternoon wind directions at Miyun in August 2006 (light blue), 2007 (blue), and 2008 (red). The radius indicates the frequency of wind observed in each direction.

traceable $\mathrm{SO}_{2}$ standard into sample air. The mixing ratio is computed by subtracting the zero offset from ambient signal voltage and multiplying by the instrument gain.

\subsection{Model description}

The nested-grid GEOS-Chem model developed by Chen et al. (2009) is employed in the present study. The GEOSChem global 3-D model for tropospheric chemistry is driven by meteorological data assimilated by the Goddard Earth Observing System (GEOS) at the NASA Global Modeling and Assimilation Office (GMAO). The present study uses GEOS5 meteorology covering the period from December 2004 to present. The meteorological data include 3-D fields updated every $3 \mathrm{~h}$ for surface fluxes and mixing depths and every $6 \mathrm{~h}$ for other variables. The horizontal resolution is $0.5^{\circ}$ latitude by $0.667^{\circ}$ longitude, with 72 levels in the vertical extending from the surface to $0.01 \mathrm{hPa}$. The lowest $2 \mathrm{~km}$ is resolved into 14 layers with midpoints at altitudes of $70,200,330$, $460,600,740,875,1015,1157,1301,1447,1594,1770$, $2000 \mathrm{~m}$ for a column based at sea level. For inputs to the global GEOS-Chem model, the horizontal resolution of the meteorological fields is degraded to $2^{\circ}$ latitude $\times 2.5^{\circ}$ longitude or $4^{\circ}$ latitude $\times 5^{\circ}$ longitude due to computational limitations. Details of the degrading process are provided by Wang et al. (2004a).

The structure of the nested-grid GEOS-Chem model involves a window with a uniform horizontal resolution of $0.5^{\circ} \times 0.667^{\circ}$ embedded in a low-resolution $\left(4^{\circ} \times 5^{\circ}\right)$ global 
background. The nested-grid GEOS-Chem retains the generic high horizontal resolution of the GEOS-5 data over the nested regional domain. For the present study, the nested domain is set at $70^{\circ} \mathrm{E}-150^{\circ} \mathrm{E}$ and $11^{\circ} \mathrm{S}-55^{\circ} \mathrm{N}$ and includes all of China, its neighboring countries, and a significant portion of the northwestern Pacific (Wang et al., 2004a; Wang et al., 2004b; Chen et al., 2009). The highresolution regional simulation is coupled dynamically to the low-resolution global model through lateral boundary conditions that are updated every three hours.

The GEOS-Chem model includes a detailed tropospheric $\mathrm{O}_{3}-\mathrm{NO}_{\mathrm{x}}$-hydrocarbon- aerosol simulation. The aerosol and oxidant chemistry are coupled through the formation of sulfate and nitrate, heterogeneous chemistry, and aerosol effects on photolysis rates. Photolysis frequencies are computed using the Fast-J radiative transfer algorithm (Wild et al., 2000) which allows for Rayleigh scattering as well as for Mie scattering by clouds and aerosols. Simulation of wet and dry deposition follows the schemes developed by Bey et al. (2001). Application and evaluation of the model over China have been described by Wang et al. (2004a, c). Anthropogenic emissions of $\mathrm{NO}_{\mathrm{x}}, \mathrm{CO}, \mathrm{SO}_{2}$, and VOCs over the nested East Asia domain were taken from Zhang et al. (2009) for the year 2006. Since our analysis focuses on the differences in model results over Beijing between 2007 and 2008, 2007 is chosen as the base year with which to represent emissions from Beijing. Anthropogenic emissions for Beijing in 2007 are taken from detailed inventory work carried out by researchers at Tsinghua University. The inventory for Beijing was developed bottom-up and has a spatial resolution of $4 \mathrm{~km} \times 4 \mathrm{~km}$. It was compiled from detailed energy statistics for Beijing, road network databases, locations of power plants and large industrial facilities, population distribution, and surveys of other key parameters related to activity rates. Emission factors for pollutants were obtained from a detailed technology-based approach reflecting rapid renewal of combustion equipment and processes, combined with field measurements of representative combustion types (S. X. Wang et al., Emission reductions and air quality improvements of air quality control measures during the 2008 Olympics in Beijing, Environ. Sci. Tech., submitted, 2009).

\section{Air quality improvement during the Olympics}

As summarized in the introduction, some emission-reduction measures started later than others, although all were in place during the time period of the Olympics (8-24 August 2008). Therefore, in order to evaluate the aggregate effects of the emission-reduction policies, most of the analysis below will focus on pollutant concentrations for August 2008. We showed in a previous study that $\mathrm{O}_{3}$ peaks in June at Miyun and that mean daytime $\mathrm{O}_{3}$ in August is on average $10 \mathrm{ppbv}$ lower than that in June (Wang et al., 2008). Other observations for Beijing have shown similar seasonal patterns in surface $\mathrm{O}_{3}$ (Ding et al., 2007; Lin et al., 2008). To minimize the compounding effects of this natural seasonal variability of $\mathrm{O}_{3}$ and other species, our analysis compares trace gas levels in August 2008 to the same periods in 2006 and 2007, rather than comparing August to June or other months of 2008. No "weekend effect" has been observed for precursor emissions in China (Beirle et al., 2003) and we did not find a "weekend effect" on $\mathrm{O}_{3}$ observed at Miyun. Therefore, we did not distinguish weekend from weekday observations in the following discussion.

\subsection{Trace gas concentrations}

Figure 2 presents mean daytime mixing ratios of $\mathrm{O}_{3}$ (Fig. 2a) and $\mathrm{CO}$ (Fig. 2b) as observed at Miyun in summer (JulyAugust-September; JAS) 2006-2008. In JAS 2008, mean daytime mixing ratios of $\mathrm{CO}$ and $\mathrm{O}_{3}$ dropped significantly compared to the same months in 2006 and 2007. The mean daytime mixing ratio of $\mathrm{CO}$ was $350 \mathrm{ppbv}$ in August 2008, about $150 \mathrm{ppbv}$ (or 30\%) lower than for August in 2006 and 2007. The mean daytime mixing ratio of $\mathrm{O}_{3}$ decreased by about 15 ppbv between August 2006-2007 and August 2008, from $65 \mathrm{ppbv}$ to $50 \mathrm{ppbv}$. During the Olympics (4 August24 August 2008), daytime $\mathrm{O}_{3}$ averaged 42 ppbv. The decreases in $\mathrm{O}_{3}$ and $\mathrm{CO}$, compared to the same months in 2006-2007, are larger than the magnitude of interannual variations observed at Miyun.

Figure 2c presents hourly mixing ratios of $\mathrm{O}_{3}$ observed at Miyun in August 2006-2008. It is clear that $\mathrm{O}_{3}$ was lowest in 2008 for almost every day in August except the few days at the beginning of the month, which were attributed to unfavorable meteorological conditions (to be discussed in Sect. 4.2). The decreases in August 2008 were most significant in the afternoon when photochemical production of $\mathrm{O}_{3}$ is most active and urban pollution plumes are transported to the site. Mixing ratios of $\mathrm{CO}$ peak in the afternoon in summer, similar to $\mathrm{O}_{3}$, indicating the arrival of urban pollution plumes (Wang et al., 2008b). The decrease in afternoon mixing ratios of $\mathrm{O}_{3}$ in August 2008 indicates reductions in chemical production of $\mathrm{O}_{3}$ in urban pollution plumes. The reduction in $\mathrm{O}_{3}$ was not only reflected in mean concentrations but also in peak concentrations. The number of hours with 1-hr average concentrations of $\mathrm{O}_{3}$ exceeding $102 \mathrm{ppbv}$ (Chinese air quality standard for ozone) decreased from an average of $25 \mathrm{~h}$ in August 2006 and 2007 to only $3 \mathrm{~h}$ in August 2008.

Figure 3 displays afternoon mixing ratios of $\mathrm{O}_{3}, \mathrm{CO}, \mathrm{NO}_{\mathrm{y}}$, and $\mathrm{SO}_{2}$ observed at Miyun in August 2006-2008 as a function of wind direction. For $\mathrm{NO}_{\mathrm{y}}$ and $\mathrm{SO}_{2}$, data are available only for 2007-2008. Lower mixing ratios of all the species were observed for most wind directions in August 2008. The largest reductions in trace gas concentrations were observed for air masses arriving from SW, SSW and S, i.e. from the Beijing urban area. Table 1 compares mean afternoon mixing ratios of the trace gases associated with SSW-SW-S winds observed at Miyun between August 2007 and 2008. For 
(a) Miyun $\mathrm{O3}$ monthly daytime mean

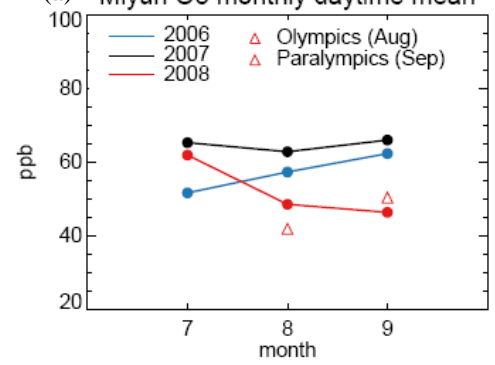

(b) Miyun CO monthly daytime mean

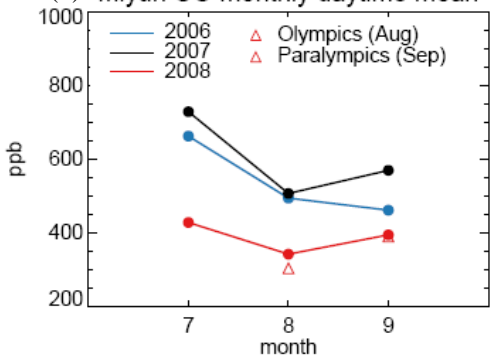

(c) $\mathrm{O}_{3}$ at Miyun August - Sep 2008

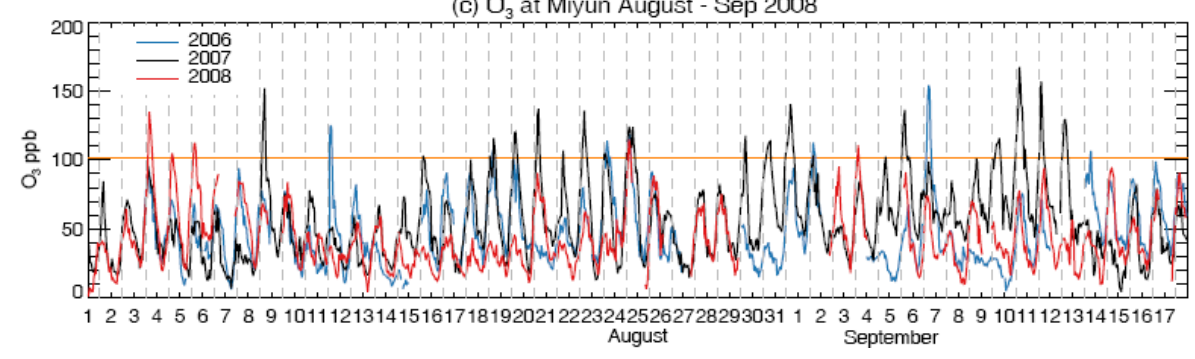

Fig. 2. Daytime mean mixing ratios of $\mathrm{O}_{3}$ (a) and $\mathrm{CO}$ (b) observed at Miyun for July-August-September of 2006 (blue line), 2007 (black line) and 2008 (red line). The triangles indicate the mixing ratios averaged for the exact time period of the Olympics Games (4-24 August 2008) and the Paralympics Games (6-17 September 2008). (c) Hourly mixing ratio of $\mathrm{O}_{3}$ observed at Miyun for the period 1 August-17 September of 2006 (blue line), 2007 (black line), and 2008 (red line).
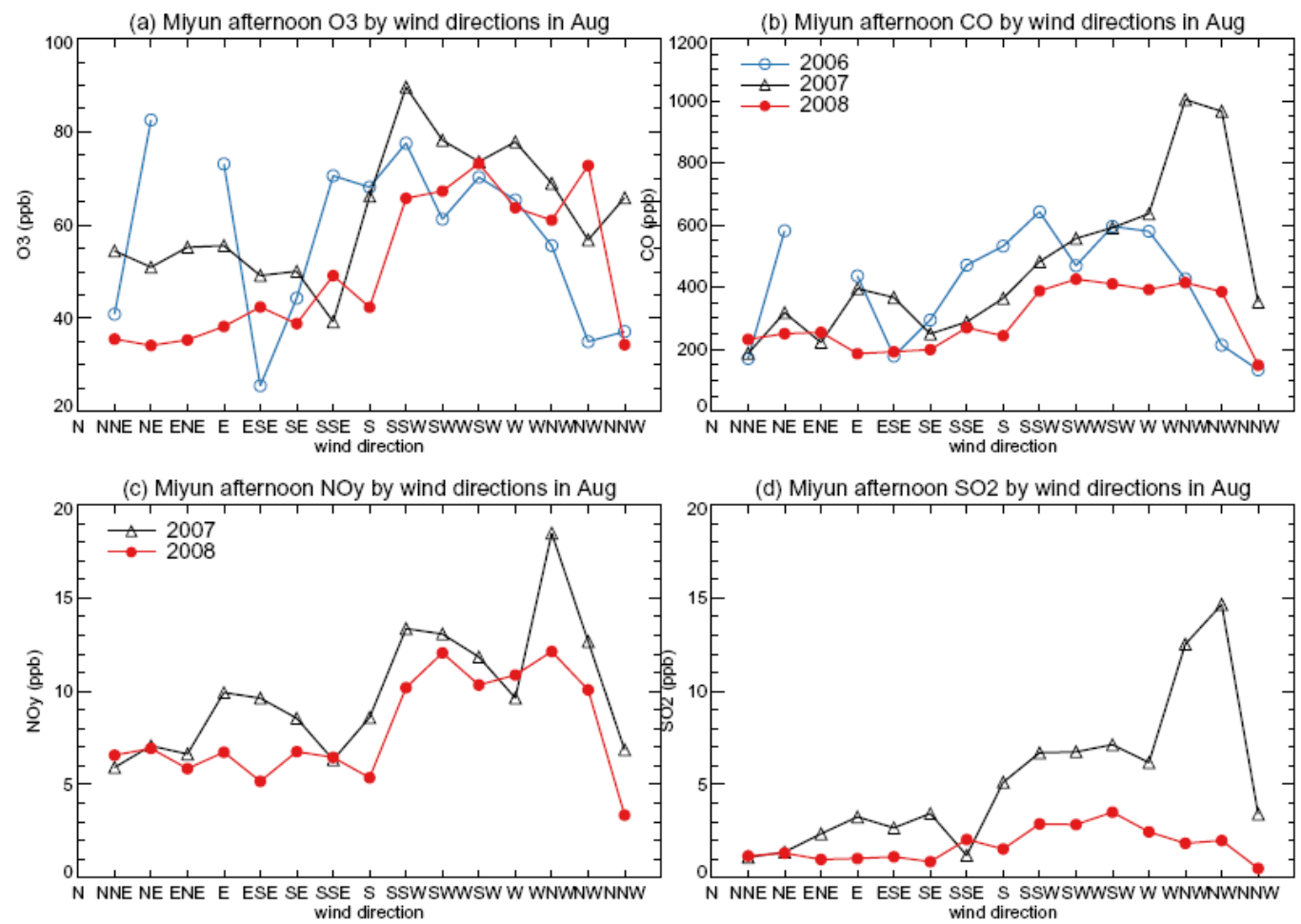

Fig. 3. Afternoon mixing ratios of $\mathrm{O}_{3}(\mathbf{a}), \mathrm{CO}(\mathbf{b}), \mathrm{NO}_{\mathrm{y}}(\mathbf{c})$, and $\mathrm{SO}_{2}(\mathbf{d})$ observed at Miyun in August as a function of wind directions. Data for August 2006 are displayed in blue, August 2007 in black, and August 2008 in red. Observations of $\mathrm{NO}_{\mathrm{y}}$ and $\mathrm{SO}_{2}$ were not available in 2006. 

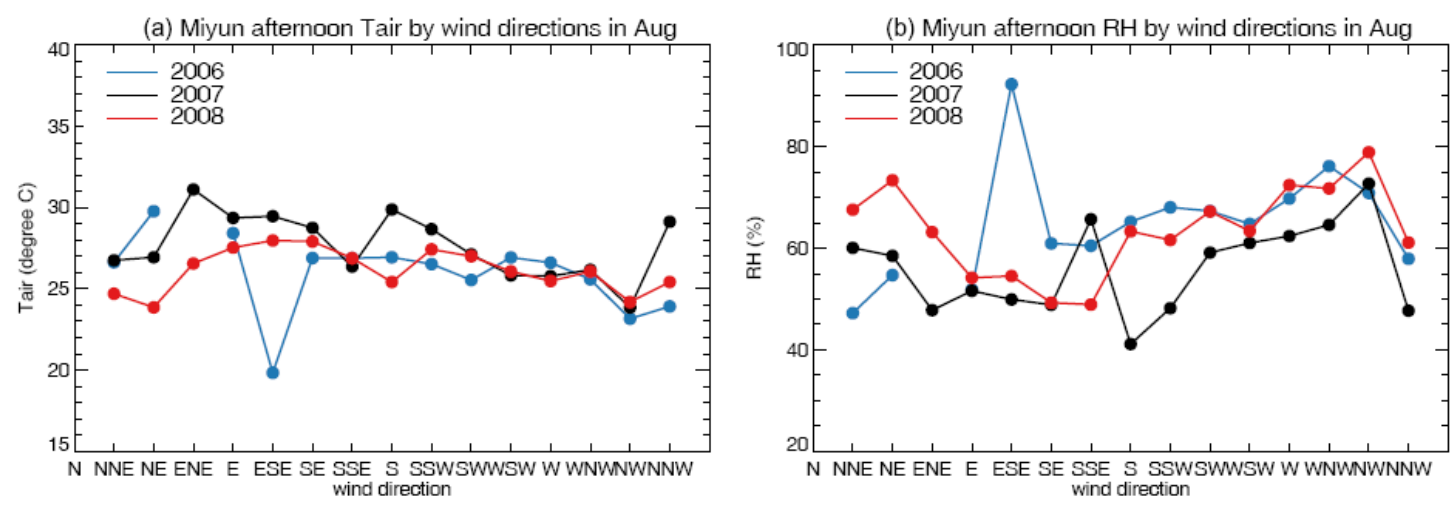

Fig. 4. Air temperature and relative humidity observed at Miyun in August as a function of wind directions. Data for August 2006 are displayed in blue, August 2007 in black, and August 2008 in red.

Table 1. Mean afternoon mixing ratios (ppbv) of $\mathrm{SO}_{2}, \mathrm{CO}, \mathrm{NO}_{\mathrm{y}}$, and $\mathrm{O}_{3}$ associated with SSW-SW-S winds observed at the Miyun site in August 2007 and 2008.

\begin{tabular}{lrrr}
\hline & August 2007 & August 2008 & Reduction (\%) \\
\hline $\mathrm{SO}_{2}$ & 6.2 & 2.4 & 61.3 \\
$\mathrm{CO}$ & 468 & 352 & 24.8 \\
$\mathrm{NO}_{\mathrm{y}}$ & 11.7 & 9.2 & 21.4 \\
$\mathrm{O}_{3}$ & 78 & 58 & 25.6 \\
\hline
\end{tabular}

these air masses, the relative reductions in mixing ratios of $\mathrm{SO}_{2}, \mathrm{CO}, \mathrm{NO}_{\mathrm{y}}$, and $\mathrm{O}_{3}$ from August 2007 to August 2008 are $61 \%, 25 \%, 21 \%$, and $26 \%$, respectively.

\subsection{Meteorological conditions}

Production and transformation of $\mathrm{O}_{3}$ depend critically on meteorology and weather patterns. In this section we compare the meteorological parameters measured at Miyun for Augusts of the three years investigated in this study. As illustrated in Fig. 1, the prevailing winds were from SSW and SW in August 2007 and 2008 and from S and SSE in August 2006. However, mixing ratios of $\mathrm{O}_{3}$ and $\mathrm{CO}$ associated with S and SSE winds in August 2006 were comparable to those associated with SW and SSW winds (c.f. Fig. 3a and b), with both representing polluted air masses from urban areas to the south of the site. Therefore, we conclude that there were no significant changes in the characteristics of air masses associated with the prevailing winds arriving at the site over Augusts of the three years.

Temperature and relative humidity (RH) are two key meteorological parameters measured at the site. Temperature controls key chemical reactions. RH is an indicator of water vapor content in the air with respect to saturation levels. It is closely associated with weather patterns. $\mathrm{RH}$ is typically higher on cloudy and precipitation days than on sunny conditions. As cloudiness and precipitation are unfavorable for photochemical production of ozone at the surface, $\mathrm{RH}$ tends to be negatively correlated with $\mathrm{O}_{3}$ (Davis et al., 1999; Elminir, 2005). Our prior study (Wang et al., $2008 \mathrm{~b}$ ) discussed the negative correlation between RH as an indicator of cloudiness and $\mathrm{O}_{3}$ in summer 2006 at the Miyun site.

Although wind direction measured locally at the site is not equal to the direction from which air masses originate, grouping observations for the whole month by wind direction can still give some statistical association with the origins of air masses. Figure 4 presents temperature and $\mathrm{RH}$ observed at Miyun in August 2006-2008 as a function of wind direction. Northeasterly winds (NNE, NE, ENE) were sampled $10 \%$ of the time in August 2008, more frequently than in either August 2006 or 2007 (2\% and 4\% of the time, respectively) (Fig. 1). As shown in Fig. 3, the mean mixing ratio of $\mathrm{O}_{3}$ in NNE-NE-ENE air masses dropped from $50 \mathrm{ppbv}$ in August 2006-2007 to $35 \mathrm{ppbv}$ in August 2008, with relatively smaller or no changes for $\mathrm{CO}, \mathrm{NO}_{\mathrm{y}}$, and $\mathrm{SO}_{2}$, suggesting that the reductions in $\mathrm{O}_{3}$ may be attributed to differences in meteorological factors such as temperature and relative humidity rather than in precursor emissions. For air masses from the NNE-NE-ENE directions, the mean temperature was $4^{\circ} \mathrm{C}$ lower in August 2008 as compared to August 2006-2007, while RH was higher by 15\% (Fig. 4). Since lower temperature and higher RH are normally considered meteorological conditions that are not conducive to photochemical production of $\mathrm{O}_{3}$, this meteorological difference could account for reduced $\mathrm{O}_{3}$ levels in NNE-NE-ENE air masses sampled in August 2008 relative to those in 2006 and 2007. However, winds from the NNE-NE-ENE sector are infrequent at the site in August, and lower $\mathrm{O}_{3}$ mixing ratio for this sector relates to short-term, day-to-day, variability in meteorology and thus can only account for $2 \mathrm{ppbv}$ of the reduction in monthly mean $\mathrm{O}_{3}$ for August 2008. The effect on other species is even smaller. Therefore, the large 

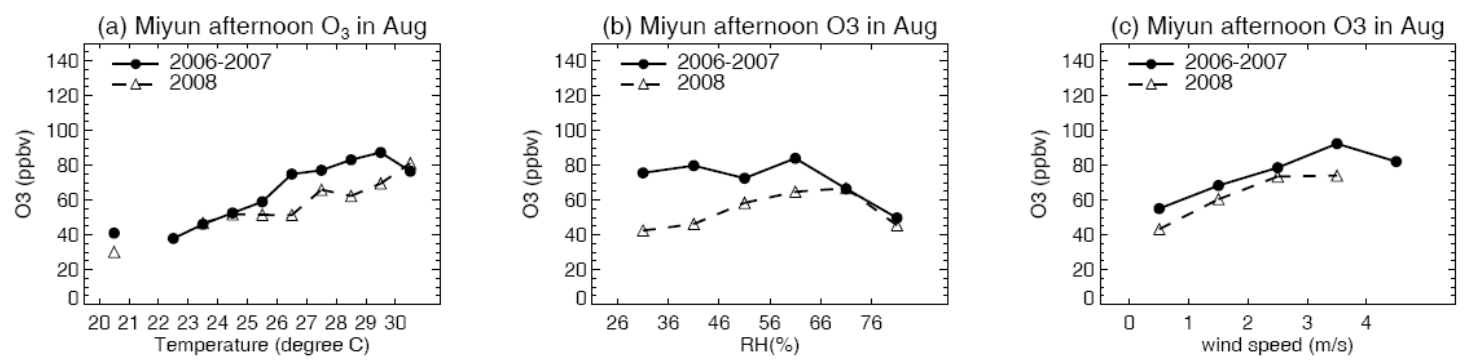

Fig. 5. Mixing ratio of afternoon mean $\mathrm{O}_{3}$ observed at Miyun in August as a function of temperature (a), $\mathrm{RH}$ (b), and wind speed (c). Data averaged for Augusts of 2006 and 2007 are indicated in solid black line, for August 2008 in dashed black line.

decreases observed for $\mathrm{O}_{3}$ and other species in August 2008 (e.g. a 15 ppbv reduction in $\mathrm{O}_{3}$ ) would have to be related to the majority of air masses from SSW-SW-S-SE directions, where significant reductions in emissions took place in the Beijing urban area during the Olympics.

For SSW-SW-S-SE air masses, mean temperature and RH in August 2008 were not significantly different during Augusts of 2006 and 2007. For these air masses, mean temperature was $27^{\circ} \mathrm{C}$ in August 2008, as compared to $26^{\circ} \mathrm{C}$ and $29^{\circ} \mathrm{C}$ in August 2006 and 2007, respectively. Average RH's in August 2006, 2007, and 2008 were 70\%, 50\%, and 60\%, respectively. The difference in the mean mixing ratios of $\mathrm{O}_{3}$ between August 2006 and 2007 is -4 ppbv, corresponding to a difference of $-3^{\circ} \mathrm{C}$ in mean temperature and $+20 \%$ in $\mathrm{RH}$. By comparison, the difference in mean $\mathrm{O}_{3}$ between $\mathrm{Au}-$ gust 2008 and 2007 is -15 ppbv, despite only a $-1{ }^{\circ} \mathrm{C}$ difference in mean temperature and a $+10 \%$ difference in $\mathrm{RH}$. This suggests that inter-annual variations in temperature and RH could not be the only explanation for the unusually low concentrations of $\mathrm{O}_{3}$ and other species observed at Miyun in August 2008.

Figure 5 presents ozone observations in August 20062008 as a function of other meteorological variables (temperature, RH, and wind speed). Each of the meteorological variables has similar ranges for Augusts of the three years, except for the lack of high wind speed sector $(>4 \mathrm{~m} / \mathrm{s})$ in August 2008 (to be discussed below). For each of the sectors of temperature, $\mathrm{RH}$, and wind speed shown in Fig. 5, mean $\mathrm{O}_{3}$ levels of Augusts 2006 and 2007 were always higher compared with August 2008. The differences tend to be larger at higher temperature and lower RH, which are typically favorable meteorological conditions for ozone pollution. This suggests that meteorology cannot be the only factor contributing to the reductions in $\mathrm{O}_{3}$ in August 2008.

Mean daytime wind speed was $1.3 \mathrm{~m} / \mathrm{s}$ in August 2008, slightly lower than that of $1.7 \mathrm{~m} / \mathrm{s}$ in August 2006 and 2007. For SSW-SW-S-SE winds, mean speed in the afternoon was $1.6 \mathrm{~m} / \mathrm{s}$ in August 2008 as compared to $2.3 \mathrm{~m} / \mathrm{s}$ in August 2007. If slower southwesterly winds could be interpreted as indicating slower and less efficient transport of pollution from the Beijing urban region, this in combination with reductions in urban pollutions during the Olympics offers a plausible explanation for lower concentrations of $\mathrm{O}_{3}$ and other pollutants observed at Miyun in August 2008.

We showed in a previous study that optically thick clouds associated with summer monsoonal rainfall have a significant radiative impact on $\mathrm{O}_{3}$ at Miyun (Wang et al., 2008b). Cloud optical depth (COD) retrieved from the Moderate Resolution Imaging Spectroradiometer (MODIS) instrument aboard the Aqua satellite (Platnick et al., 2003; MYD08_M3, MODIS level-3 monthly global product at $1^{\circ} \times 1^{\circ}$ resolution) showed slightly lower COD for August 2008 (COD=17.7), as compared to August 2007 (COD=22.6). Therefore, interannual variations in precipitation and COD were ruled out as the key factors responsible for lowering $\mathrm{O}_{3}$ as observed in August 2008.

\subsection{Species correlations and "top-down" estimates of emission reductions}

In this section, we employ an observation-based approach to derive quantitative estimates on the magnitude of emission reductions for $\mathrm{SO}_{2}, \mathrm{CO}$, and $\mathrm{NO}_{\mathrm{x}}$ during the Olympics. First, the relative reduction in emissions of $\mathrm{SO}_{2}$ is estimated from observations. $\mathrm{SO}_{2}$ has shorter lifetime than $\mathrm{NO}_{\mathrm{y}}$ and is thus less influenced by background concentrations. The reductions in emissions of $\mathrm{CO}$ and $\mathrm{NO}_{\mathrm{x}}$, relative to $\mathrm{SO}_{2}$, are inferred subsequently using the $d \mathrm{CO} / d \mathrm{SO}_{2}$ and $d \mathrm{NO}_{\mathrm{y}} / d \mathrm{SO}_{2}$ correlation slopes observed at Miyun.

Due to the relatively short lifetime of $\mathrm{SO}_{2}$ (a few hours in summer considering both gas phase and aqueous phase reactions), background $\mathrm{SO}_{2}$ concentrations at Miyun are lower than concentrations of $\mathrm{CO}$ and $\mathrm{NO}_{\mathrm{y}}$. As illustrated in Fig. 3, for the relatively clean air masses from the northeast sampled at Miyun, mean mixing ratios of $\mathrm{SO}_{2}, \mathrm{NO}_{\mathrm{y}}$, and $\mathrm{CO}$ are about $0.5 \mathrm{ppbv}, 5 \mathrm{ppbv}$, and $200 \mathrm{ppbv}$, respectively. Given the negligible background level for $\mathrm{SO}_{2}$, the difference in mixing ratio from the urban pollution plumes between August 2007 and 2008 can be assumed to be caused by changes in emissions and variations in the chemical lifetime of $\mathrm{SO}_{2}$. One can expect that the chemical lifetime of $\mathrm{SO}_{2}$ and its transport 

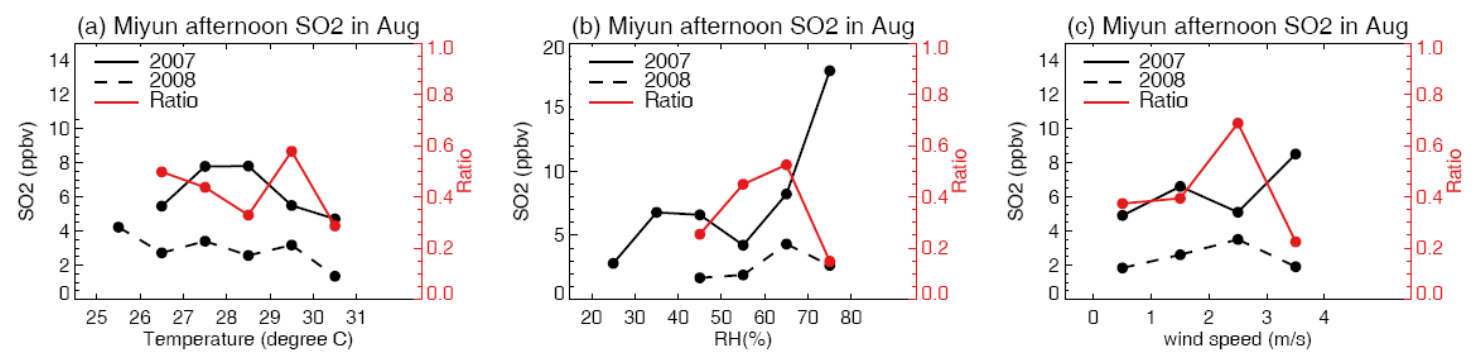

Fig. 6. Mixing ratio of $\mathrm{SO}_{2}$ observed in SW-SSW-S air masses at Miyun in August as a function of temperature (a), relative humidity (b), and wind speeds (c). Data for August 2007 are indicated in solid black line, August 2008 in dashed black line, and the ratio between August 2008 and $2007\left(\left[\mathrm{SO}_{2}\right]_{2008} /\left[\mathrm{SO}_{2}\right]_{2007}\right)$ in red line.

time from the Beijing urban area to the site depend on meteorological conditions. To separate the effects of meteorology on the lifetime of $\mathrm{SO}_{2}$, the S-SW-SSW air masses sampled at Miyun during August 2007 and 2008 were divided into several data intervals according to their temperature, $\mathrm{RH}$, and wind speed. Under the constraint that each interval contain at least five observational data points for each month to allow for statistical representation, we identified 6 intervals by temperature, 6 by RH, and 4 by wind speed, as illustrated in Fig. $6 \mathrm{a}, \mathrm{b}$, and c, respectively. Mean mixing ratios of $\mathrm{SO}_{2}$ were calculated for each interval as well as the ratio in $\mathrm{SO}_{2}$ between August 2007 and $2008\left(\left[\mathrm{SO}_{2}\right]_{2008} /\left[\mathrm{SO}_{2}\right]_{2007}\right)$. The mean ratio averaged for all the intervals is assumed to indicate reductions in emissions, while the variance about the mean represents random variations in the chemical lifetime and transport time of $\mathrm{SO}_{2}$ at Miyun. We found that the mean ratio in $\mathrm{SO}_{2}$ (weighted by the frequency of the meteorology classes in Fig. 6) was $40 \%$ and the variance in $\mathrm{SO}_{2}$ lifetime was $10 \%$, representing the uncertainty in our estimate of emission reductions. We estimated therefore that during the Olympics period (i.e. August 2008), $\mathrm{SO}_{2}$ emissions in Beijing were reduced by $60 \%$ ( $\pm 10 \%$ uncertainty) compared with the same month the year earlier.

We caution that this approach does not take into account the affect of changing oxidant levels (i.e. $\mathrm{OH}, \mathrm{O}_{3}$, and $\mathrm{H}_{2} \mathrm{O}_{2}$ ) during the Olympics on the chemical lifetime of $\mathrm{SO}_{2}$. Given the $25 \%$ reduction in $\mathrm{O}_{3}$ levels during the Olympics, the lifetime of $\mathrm{SO}_{2}$ against the aqueous phase oxidation may be reduced accordingly, resulting in less loss of $\mathrm{SO}_{2}$ over the course of transport from the urban area to the site. The same argument holds for the gas phase oxidation of $\mathrm{SO}_{2}$, considering the affect of reducing $\mathrm{NO}_{\mathrm{x}}$ and $\mathrm{O}_{3}$ on $\mathrm{OH}$. Therefore, our estimate of $60 \%$ reduction in $\mathrm{SO}_{2}$ emissions derived above is a conservative estimate. Our later modeling analysis (Sect. 4.1) indicates that use of the Olympics emissions for all the species in the model results in an average of $42 \%$ reduction in simulated $\mathrm{SO}_{2}$ concentrations at Miyun, less than a perfect linear response to the $60 \%$ reduction in $\mathrm{SO}_{2}$ emissions. A robust estimate of the $\mathrm{SO}_{2}$ emission reductions would require an inverse modeling approach. As the focus of the present study is to demonstrate the effectiveness of emission reductions during the Olympics on air quality improvement, use of the conservative emission estimates would not weaken our conclusions.

Figure 7 shows scatterplots of $\mathrm{NO}_{\mathrm{y}}$ versus $\mathrm{CO}$ (Fig. 7a), $\mathrm{SO}_{2}$ versus $\mathrm{CO}$ (Fig. 7b), and $\mathrm{SO}_{2}$ versus $\mathrm{NO}_{\mathrm{y}}$ (Fig. 7c) observed at Miyun during August 2007 and 2008. As we are interested primarily in pollution from the Beijing urban area, the figure presents only data for the SSW-SW-S air masses sampled at Miyun. Linear regressions for the observations are obtained with the reduced major axis (RMA) method that allows for uncertainty in both variables (Hirsch and Gilroy, 1984). The three species are positively correlated at Miyun, suggesting that they originate from co-located sources. The enhancement ratios between two species (e.g. $d \mathrm{CO} / d \mathrm{SO}_{2}$ ), derived from the slope of the regression line, provide useful constraints on their emission ratios. Since the Miyun site is somewhat removed from fresh urban emissions, the enhancement ratios measured at the site will be affected also by differences in lifetimes between the species. In the following analysis, focusing on relative instead of absolute changes in enhancement ratios between August 2007 and 2008, we shall assume that the lifetime ratio between the species does not change significantly between the two periods, given that meteorological variability influences the lifetime of all the species.

The $d \mathrm{CO} / d \mathrm{NO}_{\mathrm{y}}$ enhancement ratio at Miyun is $37.5 \mathrm{~mol} / \mathrm{mol}$ in August 2008, similar to the value of $36.5 \mathrm{~mol} / \mathrm{mol}$ observed in August 2007, indicating that the fractional reduction of emissions was similar for $\mathrm{CO}$ and $\mathrm{NO}_{\mathrm{x}}$ in August 2008. In contrast, the $d \mathrm{CO} / d \mathrm{SO}_{2}$ and $d \mathrm{NO}_{\mathrm{y}} / d \mathrm{SO}_{2}$ enhancement ratios in August 2008 are significantly larger than values observed in August 2007. This suggests that the fractional reduction of $\mathrm{SO}_{2}$ emissions in August 2008 is much greater than that for $\mathrm{CO}$ or $\mathrm{NO}_{\mathrm{x}}$, resulting in the observed increases in the enhancement ratio of $\mathrm{CO} / \mathrm{SO}_{2}$ and $\mathrm{NO}_{\mathrm{y}} / \mathrm{SO}_{2}$.

The relative reduction in $\mathrm{CO}$ and $\mathrm{NO}_{\mathrm{x}}$ emissions can be inferred using the $d \mathrm{CO} / d \mathrm{SO}_{2}$ and $d \mathrm{NO}_{\mathrm{y}} / d \mathrm{SO}_{2}$ enhancement ratios observed at Miyun. As shown in Fig. $7, d \mathrm{CO} / d \mathrm{SO}_{2}$ 

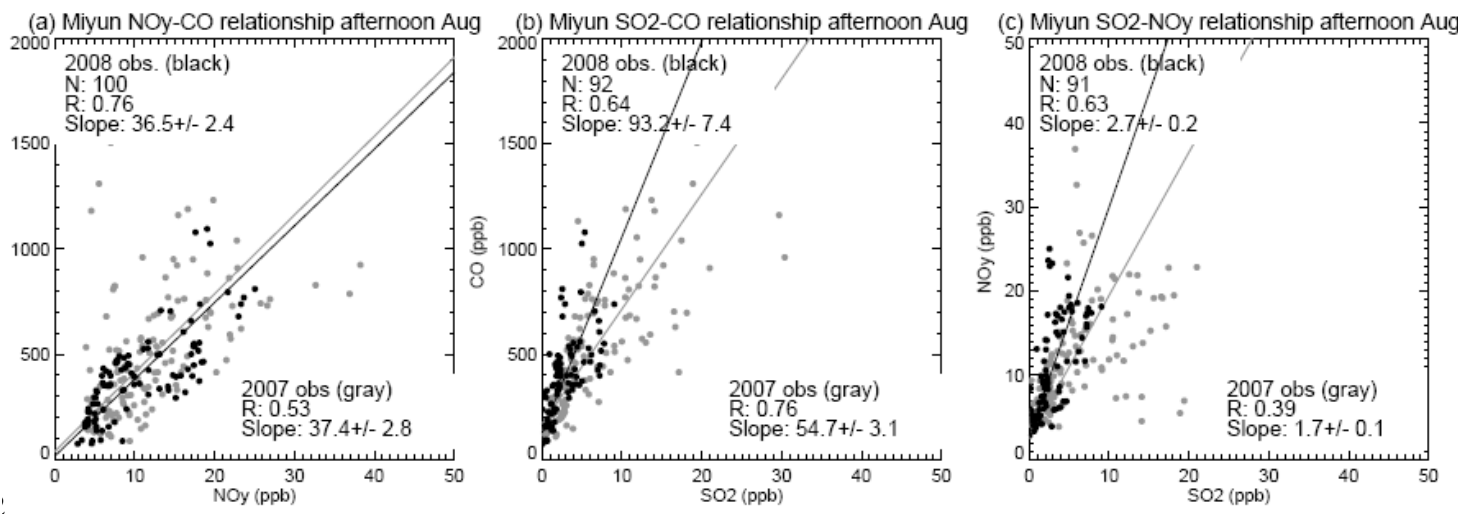

Fig. 7. (a) $\mathrm{NO}_{\mathrm{y}}-\mathrm{CO}$ relationship in afternoon observations at Miyun in August 2007 (gray dots) and August 2008 (black dots). Each point refers to hourly mean mixing ratios. Correlation coefficients $(R)$ and slopes of the reduced major-axis regression lines are shown in inset; (b) same as (a), but for $\mathrm{SO}_{2}-\mathrm{CO}$ relationship; (c) same as (a), but for $\mathrm{SO}_{2}-\mathrm{NO}_{\mathrm{y}}$ relationship.

increased from $54.7 \mathrm{~mol} / \mathrm{mol}( \pm 3.1)$ in August 2007 to $93.2 \mathrm{~mol} / \mathrm{mol}( \pm 7.5)$ in August 2008. Given a 60\% reduction in $\mathrm{SO}_{2}$ emissions derived above, this suggests a $32 \%( \pm 14 \%$ uncertainty) reduction in $\mathrm{CO}$ emissions during the Olympics. Similarly, $d \mathrm{NO}_{\mathrm{y}} / d \mathrm{SO}_{2}$ increased from $1.7 \mathrm{~mol} / \mathrm{mol}( \pm 0.1)$ in August 2007 to $2.7 \mathrm{~mol} / \mathrm{mol}( \pm 0.2)$ in August 2008, suggesting a $36 \%( \pm 14 \%)$ reduction in $\mathrm{NO}_{\mathrm{x}}$ emissions. The relative emission reductions derived here using atmospheric measurements can be regarded as "top-down" in contrast to the "bottom-up" method based on analyzing changes in energy consumption or emission factors. Our "top-down" estimate suggests that in August 2008, total emissions of $\mathrm{SO}_{2}$, $\mathrm{CO}$, and $\mathrm{NO}_{\mathrm{x}}$ in Beijing were reduced by $60 \%, 32 \%$, and $36 \%$, respectively, compared to the same month the year before.

Our results suggest that the emission control on $\mathrm{SO}_{2}$ was most effective during the Olympics. Emissions of $\mathrm{SO}_{2}$ originate largely from coal-burning point sources such as power plants and industrial boilers, while sources of $\mathrm{CO}$ and $\mathrm{NO}_{\mathrm{x}}$ are more diversified. Transportation accounts for a large fraction of emissions for both $\mathrm{CO}$ and $\mathrm{NO}_{\mathrm{x}}$, while the power sector is a greater contributor to both $\mathrm{SO}_{2}$ and $\mathrm{NO}_{\mathrm{x}}$. The flue gas desulphurization (FGD) equipment installed on power plants in Beijing and mandated to operate at full capacity since June 2008 (Wang et al., submitted, 2009) can remove over $95 \%$ of $\mathrm{SO}_{2}$ from smoke stacks, whereas $\mathrm{NO}_{\mathrm{x}}$-control technologies with the same effectiveness such as SCR (Selective Catalytic Reduction) are not widely installed because of high cost involved. The low-NOx burner technology adopted in current Chinese power plants can reduce $\mathrm{NO}_{\mathrm{x}}$ emissions only by $30 \%$ at most (Zhao et al., 2009). Control measures targeted at the power sector would therefore be more effective in reducing $\mathrm{SO}_{2}$ relative to $\mathrm{NO}_{\mathrm{x}}$, resulting in increases in the $\mathrm{NO}_{\mathrm{x}} / \mathrm{SO}_{2}$ ratio. The traffic restriction during the Olympics would decrease the $\mathrm{CO} / \mathrm{NO}_{\mathrm{x}}$ ratio because of the strict ban placed on old, inefficient vehicles that failed to meet the European No. I standards for exhaust emissions. However, control on power plant emissions would increase the $\mathrm{CO} / \mathrm{NO}_{\mathrm{x}}$ ratio as power plants are minor sources for CO. As a result, $d \mathrm{CO} / d \mathrm{NO}_{\mathrm{y}}$ enhancement ratio observed at Miyun did not change significantly from August 2007 to 2008 , leading to comparable estimates on emission changes for $\mathrm{CO}$ and $\mathrm{NO}_{\mathrm{x}}$.

Researchers at Tsinghua University conducted a detailed bottom-up study of Beijing emissions during the Olympics period based on roadside traffic monitoring, emission measurements at the smoke stacks of selected power plants, statistics on industrial output reductions and plant closures, and other information on activity levels and emission factors (Wang et al., submitted, 2009). Their estimated emission reductions were $58 \%, 51 \%$, and $55 \%$ for $\mathrm{SO}_{2}, \mathrm{CO}$, and $\mathrm{NO}_{\mathrm{x}}$. Our estimate of the reductions is consistent with the bottom-up estimate for $\mathrm{SO}_{2}$ but is lower for $\mathrm{NO}_{\mathrm{x}}$ and $\mathrm{CO}$. On one hand, the difference is consistent with our above analysis that our top-down estimates are subject to low biases. On the other hand, the discrepancy may be attributed to certain types of emissions not included in the bottom-up study, such as biofuel combustion in rural areas surrounding Beijing, biological emissions of $\mathrm{NO}_{\mathrm{x}}$ from soils, and $\mathrm{CO}$ produced from decomposition of VOCs. These types of emissions, which are important sources for $\mathrm{CO}$ and $\mathrm{NO}_{\mathrm{x}}$ but not for $\mathrm{SO}_{2}$, are unlikely to have been impacted by measures taken to reduce emissions of pollutants during the Olympics. Allowing for their contributions in the bottom-up study, the estimated emission reductions for $\mathrm{CO}$ and $\mathrm{NO}_{\mathrm{x}}$ would have been lower. Our "top-down" estimates are based on observational data, accounting for the composite impact of all the emission sources.

The bottom-up study estimated that VOCs emissions in Beijing were reduced by $59 \%$ during the Olympics compared with August 2007. As VOCs species were not measured at Miyun, we adopted the bottom-up estimate in the 
(a) Miyun $\mathrm{O} 3$ (afternoon mean) in August 2008
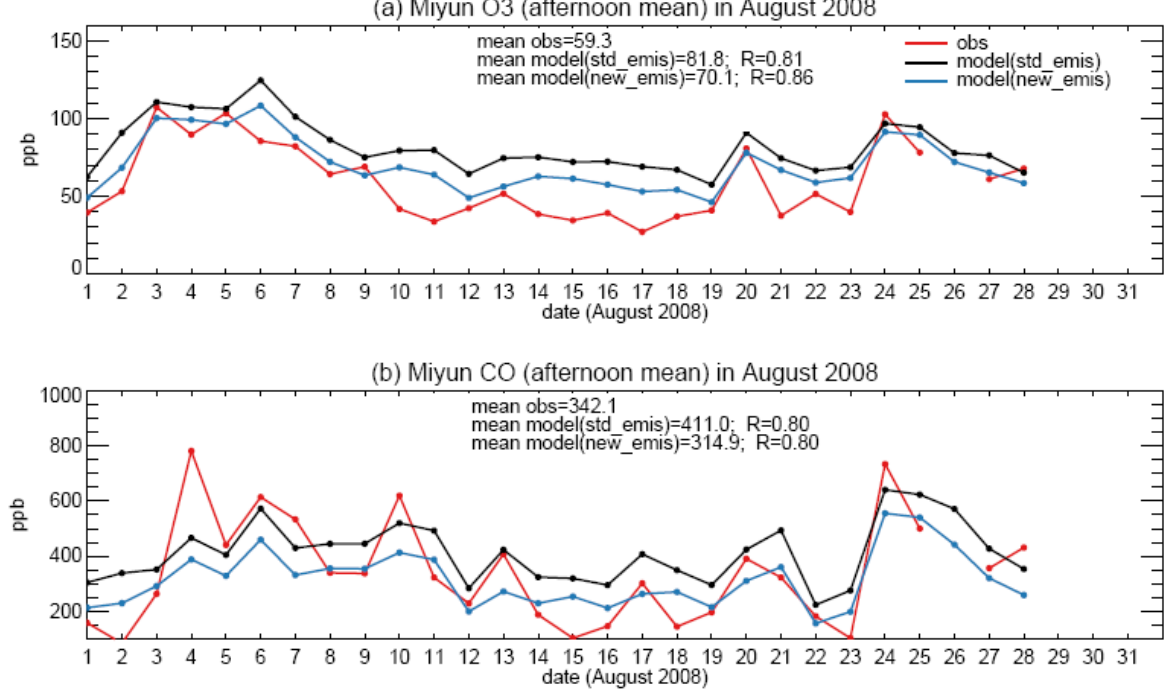

(c) Miyun NOy (afternoon mean) in August 2008

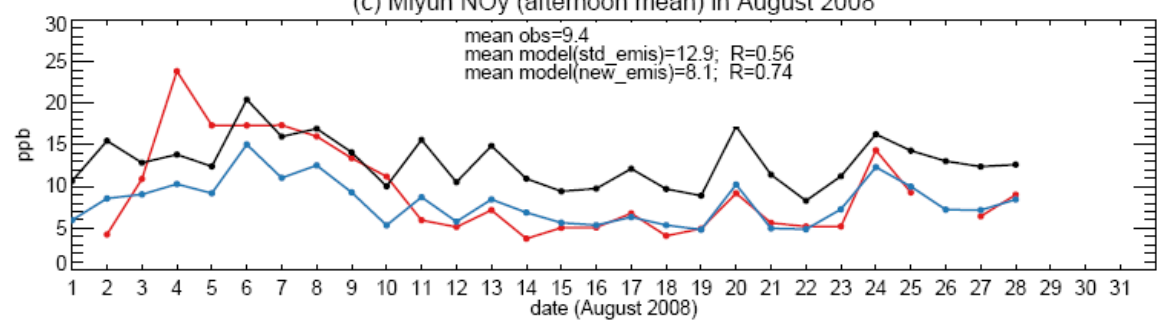

(d) Miyun SO2 (afternoon mean) in August 2008

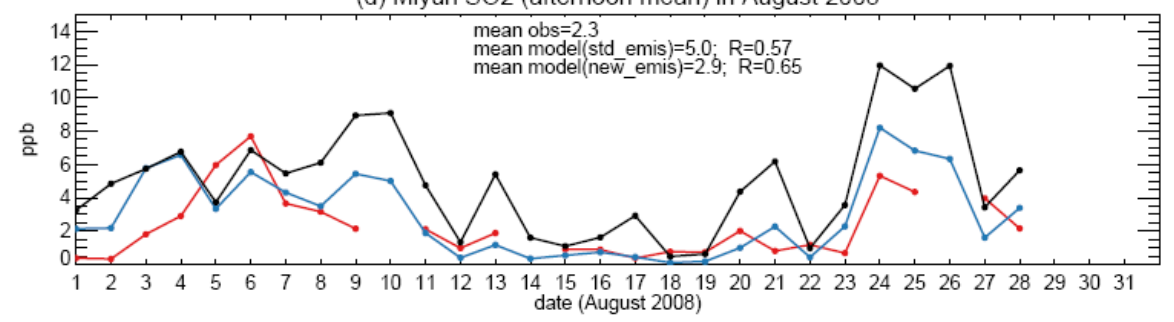

Fig. 8. Day-to-day variations in $\mathrm{O}_{3}(\mathbf{a}), \mathrm{CO}(\mathbf{b}), \mathrm{NO}_{\mathrm{y}}(\mathbf{c})$, and $\mathrm{SO}_{2}(\mathbf{d})$ at Miyun in August 2008. Observations are indicated in red, the GEOS-Chem model results using the standard emissions in black and the model results using the Olympics emissions in blue.

model simulation discussed below. The top-down estimates of $\mathrm{SO}_{2}, \mathrm{CO}$, and $\mathrm{NO}_{\mathrm{x}}$ emissions (i.e. reduction of $60 \%, 32 \%$, and $36 \%$ relative to August 2007) and bottom-up estimates of VOCs emissions (i.e. reduction of 59\%) combined here are referred to as the Olympics emissions over Beijing in what follows. Emission reductions for other regions during the Olympics were taken from bottom-up estimates by researchers at Peking University (S. Q. Zhang, personal communications).

\section{Model analysis}

In this section, we first evaluate the performance of the nested-grid GEOS-Chem in simulating the changes in $\mathrm{O}_{3}$ and other species observed at Miyun during the Olympics. The model will evaluate the top-down emissions and simulate the impact of emission reductions on the regional atmosphere.

\subsection{Model evaluation of emissions}

Figure 8 presents day to day variations of afternoon mean mixing ratios of $\mathrm{O}_{3}, \mathrm{CO}, \mathrm{NO}_{\mathrm{y}}$, and $\mathrm{SO}_{2}$ at Miyun in $\mathrm{Au}-$ gust 2008. Observations are indicated by the red lines. Significant day-to-day variations were observed for all species at Miyun, with higher pollution levels during the first five 
Table 2. Observed and modeled anomaly of afternoon $\mathrm{O}_{3}(\mathrm{ppb})$ for August 2008 and its decomposition averaged for different days in August.

\begin{tabular}{l|lrrr}
\hline & August 1-28 & August 1-7 & August 8-24 \\
\hline \multicolumn{2}{c}{ Observed anomaly (composite) } & -12.7 & 16 & -26 \\
Modeled & Composite & -11.2 & 14 & -22 \\
anomaly and & Meteorology-driven & -2.3 & 25 & -12 \\
decomposition & Emission-driven & -8.9 & -11 & -10 \\
\hline
\end{tabular}

days of August. Since all emission reduction measures had been put in place before 1 August 2008, emissions were expected to stay relatively constant throughout August except on the opening day of the Olympic Games (8 August), which was declared a public holiday for Beijing. Emissions from the transportation and industry sectors were likely lower on that day. Observations at Miyun indicate that mixing ratios of $\mathrm{O}_{3}, \mathrm{CO}, \mathrm{NO}_{\mathrm{y}}$, and $\mathrm{SO}_{2}$ were lower apparently on $8 \mathrm{Au}-$ gust compared with the day before, although the impact is expected to have lasted for at most a couple days. Day-today variability in mixing ratios at Miyun presumably reflects changes due to variations in meteorological conditions and chemical lifetimes of relevant chemical species.

In Fig. 8, model results computed using the standard emissions for 2007 are displayed in black while those using assumed Olympics emissions are displayed in blue. With the standard 2007 emissions, the model captures well the temporal variability of all four species observed at Miyun, with correlation coefficients $(r)$ ranging from 0.56 to 0.8 . This suggests that the day-to-day variations in individual species are driven primarily by changes in meteorology and chemistry, features that are accurately reproduced by the model. However, absolute values of model results obtained using the standard emissions are significantly higher than observational results for all the species, confirming the benefit to air quality of the emission restrictions implemented during the Olympics. The biases between model and observation average are $+25 \mathrm{ppbv}(+41 \%)$ for $\mathrm{O}_{3},+70 \mathrm{ppbv}(+21 \%)$ for $\mathrm{CO}$, $3.5 \mathrm{ppbv}(+37 \%)$ for $\mathrm{NO}_{\mathrm{y}}$, and $2.7 \mathrm{ppbv}(+113 \%)$ for $\mathrm{SO}_{2}$.

Adopting the Olympics emissions in the model results in a significant decrease in the mixing ratios of $\mathrm{O}_{3}, \mathrm{CO}, \mathrm{NO}_{\mathrm{y}}$, and $\mathrm{SO}_{2}$ simulated for Miyun (Fig. 8), thus reducing the model bias by more than a factor of two for all species. After implementing the Olympics emission reductions, mean mixing ratios simulated by the model are reduced by $15 \%$ (or $12 \mathrm{ppb}$ ) for $\mathrm{O}_{3}, 24 \%$ (96 ppb) for $\mathrm{CO}, 36 \%$ (4.8 ppb) for $\mathrm{NO}_{\mathrm{y}}$, and $42 \%$ (2.1 ppb) for $\mathrm{SO}_{2}$, compared with those based on the standard emissions, with no significant biases between model and observation for $\mathrm{CO}, \mathrm{NO}_{\mathrm{y}}$, and $\mathrm{SO}_{2}$. The ability of the model to simulate day-to-day variations in observations is also improved by adopting the Olympics emissions. The correlation coefficients between model and observation for $\mathrm{O}_{3}, \mathrm{NO}_{\mathrm{y}}$, and $\mathrm{SO}_{2}$ increase to $0.86,0.75$, and 0.65 from their corresponding values of $0.81,0.56$, and 0.54 in the standard simulation. We conclude therefore that the use of the Olympics emissions significantly improves the performance of the model in simulating the observations at Miyun.

Model sensitivity analysis was conducted to evaluate the relative contribution to air quality improvements in Beijing during the Olympics of local versus regional emission restrictions. We found that $80 \%$ of the concentration decreases simulated at Miyun during the Olympics resulted from a reduction in emissions from Beijing, with regional emission reductions accounting for an additional $20 \%$ decrease.

\subsection{Influences of meteorology and emissions}

Since the model has been demonstrated to reproduce well the variability in meteorology and chemistry, model sensitivity analysis was conducted to quantify the extent to which meteorological conditions were responsible for the improvement in ozone air quality in Beijing during the Olympics. The model was spun up for three months from 1 March 2006, and results for 1 June 2006 were saved to provide the initial conditions for subsequent simulations. The model was run from June to August for each of the three years (2006-2008), all using the same initial conditions obtained from the spin-up for 1 June 2006 and using the standard emissions for 2007. The Olympics emissions described above were then adopted to drive the model simulation for August 2008 only. Hourly model outputs for the Augusts of the three years were used for analysis.

We define the daily $\mathrm{O}_{3}$ anomaly in August 2008 as the deviation of afternoon-mean $\mathrm{O}_{3}$ from its mean values in 2006 and 2007. The daily $\mathrm{O}_{3}$ anomaly calculated from the model using the same standard emissions for August 2006-2008 can be thought of as representing the change in $\mathrm{O}_{3}$ during the Olympics that is not related to emission restrictions, and we refer to it as the meteorology-driven anomaly. The $\mathrm{O}_{3}$ anomaly derived from model results using the Olympics emissions for August 2008 is called the composite anomaly as the model in this case takes into account both meteorology and emissions specific to August 2008. The difference between the composite anomaly and the meteorology-driven anomaly is regarded to be the emission-driven anomaly. Figure 9 a compares the observed daily $\mathrm{O}_{3}$ anomaly at Miyun (solid line) with the composite anomaly simulated by the model (dashed line). The daily anomaly in both model and 
(a) Daily $\mathrm{O}_{3}$ anomaly at Miyun site in 2008

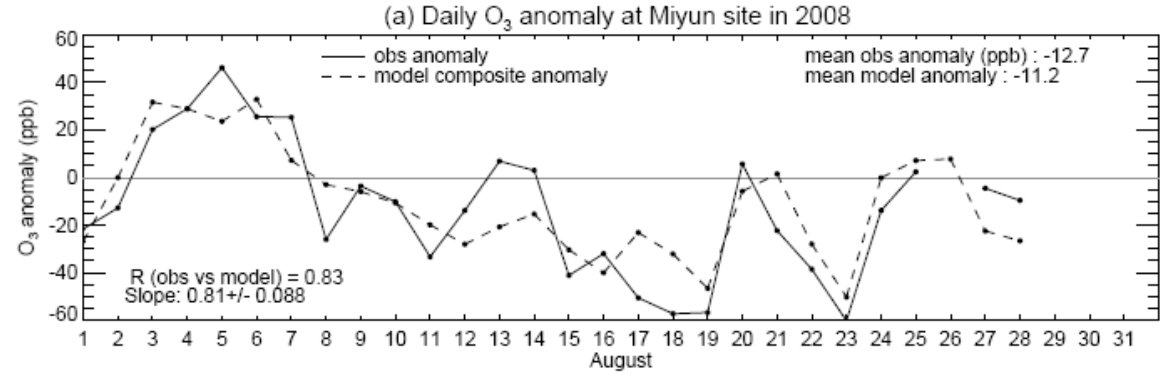

(b) Decomposition of modeled $\mathrm{O}_{3}$ anomaly at Miyun site in 2008

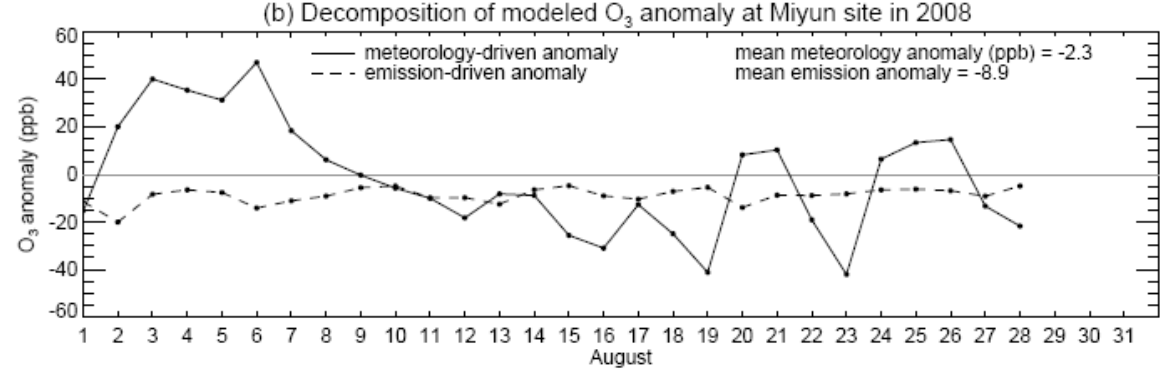

Fig. 9. (a) Daily $\mathrm{O}_{3}$ anomaly in August 2008 at Miyun. The observed anomaly is shown in solid lines and the modeled anomaly in dashed lines. The daily $\mathrm{O}_{3}$ anomaly is defined as the deviation of afternoon mean $\mathrm{O}_{3}$ in August 2008 from the mean values in August 2006 and 2007. (b) The meteorology-driven $\mathrm{O}_{3}$ anomaly (solid line) and the emission-driven anomaly (dashed line) as simulated by the GEOS-Chem model.

observation ranges from $-60 \mathrm{ppb}$ to $40 \mathrm{ppb}$. Positive anomalies were observed to occur frequently before 8 August, after which, negative anomalies prevailed. The model was found to reproduce well the daily $\mathrm{O}_{3}$ anomaly observed at Miyun in August 2008: the correlation coefficient between model and observation is 0.83 . The mean $\mathrm{O}_{3}$ anomaly simulated by the model is $-11.2 \mathrm{ppb}$, consistent with the mean of $-12.7 \mathrm{ppb}$ reflected in the observational data. With the model reproducing well the observed anomaly, we assume that the model can do a satisfactory job in distinguishing the meteorologydriven anomaly from the emission-driven anomaly, which cannot be separated in observational data.

Figure $9 \mathrm{~b}$ presents the meteorology-driven anomaly (solid line) and the emission-driven anomaly (dashed line) predicted by the model. The meteorology-related anomaly has significant day-to-day variations, ranging from $-40 \mathrm{ppb}$ to $+40 \mathrm{ppb}$. In contrast, the emission-driven anomaly is always negative, ranging from $-20 \mathrm{ppb}$ to $-5 \mathrm{ppb}$, confirming the benefit of emission restrictions in reducing $\mathrm{O}_{3}$ pollution over Beijing regardless of meteorological conditions. Compared with the meteorology-driven anomaly, the variability in the emission-driven anomaly is much smaller. The good temporal correlation between the meteorologyrelated and the composite anomaly indicates that the anomaly on individual days is mostly driven by meteorology. Table 2 summarizes mean anomalies for different days in August 2008. The large positive meteorology anomaly during the first week of August $(+25 \mathrm{ppb})$ indicates that high $\mathrm{O}_{3}$ levels during this period were largely meteorology driven, when the atmosphere was stagnant with weak southwesterly winds and high temperature. Although the emissiondriven anomaly $(-11 \mathrm{ppb})$ cannot fully compensate for the meteorology-driven anomaly during this period, it reduces the composite anomaly (+14 ppb) to $60 \%$ of the meteorology anomaly, suggesting the benefit of reducing emissions of $\mathrm{O}_{3}$ precursors during polluted days. During the Olympics (8 August-24 August), both the meteorology-driven and emission-driven anomalies are negative, averaging $-12 \mathrm{ppb}$ and $-10 \mathrm{ppb}$ respectively. The meteorology-driven anomaly appears to account for a slightly larger fraction (55\%) of the composite anomaly than the emission-driven anomaly (45\%) during this period. However, the difference between the two anomalies is only $2 \mathrm{ppb}$, within typical error bounds of chemical transport models for $\mathrm{O}_{3}$ simulation. Averaged for the whole of August 2008, however, the mean emission-driven anomaly is $-8.9 \mathrm{ppb}$, accounting for $80 \%$ of the composite anomaly and larger than the meteorology-driven anomaly $(-2.3 \mathrm{ppb})$ by a factor of 4 . We conclude that although the day-to-day variability in ozone is driven mostly by meteorology, the reduction in emissions of ozone precursors associated with the Olympic Games is responsible for at least half of the observed decrease in $\mathrm{O}_{3}$ during August 2008. 
(a) PBL mean $\mathrm{O} 3$ (standard emis)

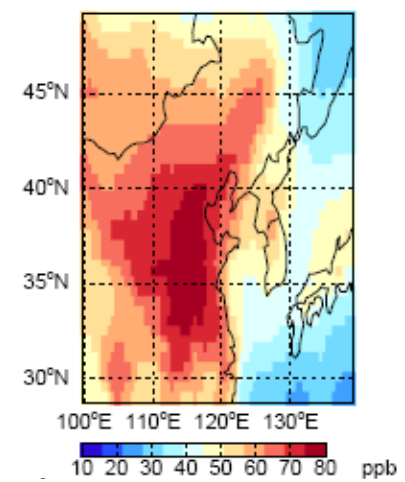

(b) $\mathrm{O} 3$ reductions in $\mathrm{PBL}$

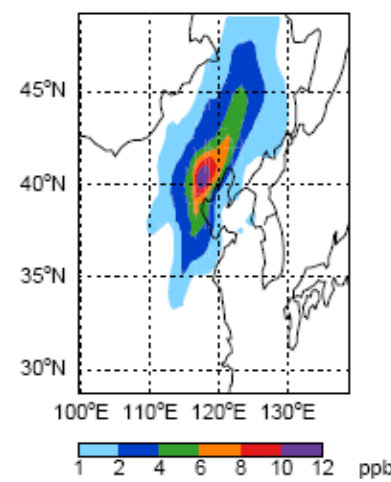

(c) $\mathrm{O} 3$ reductions in $\mathrm{FT}$

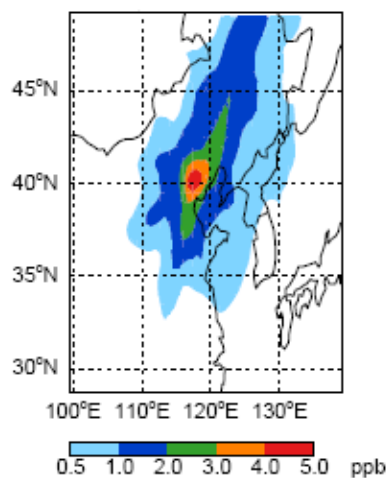

Fig. 10. (a) Monthly mean afternoon $\mathrm{O}_{3}$ averaged over the planetary boundary layer (PBL; $0-2 \mathrm{~km}$ ) simulated by the GEOS-Chem model using the standard emissions for August 2008; (b) Reductions in PBL $\mathrm{O}_{3}$ indicated by model results using the Olympics emissions as compared with the standard emissions; (c) same as (b), but for $\mathrm{O}_{3}$ reductions in the free troposphere $(2-5 \mathrm{~km})$.

\subsection{Regional impact of emission reductions}

Figure 10a shows monthly mean afternoon $\mathrm{O}_{3}$ averaged over the planetary boundary layer (PBL; $0-2 \mathrm{~km}$ ) simulated by the GEOS-Chem model using the standard emissions for August 2008. The model predicts that high ozone levels exceeding $70 \mathrm{ppbv}$ are located over the North China Plain $\left(32^{\circ}-\right.$ $40^{\circ} \mathrm{N}, 110^{\circ}-120^{\circ} \mathrm{E}$ ). Ozone mixing ratios are relatively low in south China and northeastern China. Use of the Olympics emissions in the model decreases the simulated $\mathrm{O}_{3}$ mixing ratios over the Beijing urban area and the surrounding regions. Previous studies showed that the Beijing urban area was in a VOC-limited regime (Chou et al., 2009), while the surrounding suburban and rural areas were $\mathrm{NO}_{\mathrm{x}}$-limited (Wang et al., 2006). As the spatial resolution of the model is not sufficient to simulate the nonlinear dependence of ozone production on $\mathrm{NO}_{\mathrm{x}}$ at the urban scale, the simulated reduction in ozone over the Beijing urban area during the Olympics needs to be validated by urban observations. As a result of the combined effects of both $\mathrm{NO}_{\mathrm{x}}$ and VOCs emission reductions during the Olympics, the model successfully reproduced changes in ozone concentrations observed at the Miyun site, $100 \mathrm{~km}$ downwind of Beijing, where the ozone production is expected to be more linear.

Figures $10 \mathrm{~b}$ and $\mathrm{c}$ display the spatial distribution of the resulting reduction in $\mathrm{O}_{3}$, averaged separately over the PBL and over the free troposphere $(2-6 \mathrm{~km})$ respectively. As expected, the largest reduction is found over Beijing, averaging about $12 \mathrm{ppbv}$ for August 2008. Because of the control on regional emissions as well as the relatively long lifetime of $\mathrm{O}_{3}$, the impact of the imposed reduction in emissions is found to extend far beyond the Beijing urban area, covering a large region over the North China Plain and Northeastern China. Both the magnitude and spatial extension of the simulated reductions are larger to the northeast of Beijing than to its southeast, reflecting the direction of the prevailing winds during this season. Within the PBL, the areas with mean $\mathrm{O}_{3}$ reductions exceeding $4 \mathrm{ppbv}$ extend northeastward from Beijing to about $45^{\circ} \mathrm{N}$ in Jilin province and southeastward to about $37^{\circ} \mathrm{N}$ in Hebei province. The reduction in the FT is about 50\% less than in the PBL. The 2 ppb reduction isopleth in the FT extends northeastward from Beijing to about $45^{\circ} \mathrm{N}$ in Jilin province and southeastward to about $37^{\circ} \mathrm{N}$ in Hebei province.

\section{Concluding Remarks}

To improve air quality during the Olympics (8-24 August 2008) and the Paralympics (9-17 September 2008), a series of aggressive measures was implemented by the Chinese government to reduce pollutant emissions in Beijing and surrounding areas, in place for more than two months during the interval of the two Games. We conclude that the emission restrictions were notably successful in improving air quality over Beijing. In August 2008, significant reductions in mixing ratios of $\mathrm{O}_{3}, \mathrm{CO}, \mathrm{NO}_{\mathrm{y}}$, and $\mathrm{SO}_{2}$ were detected at Miyun, a rural site located $100 \mathrm{~km}$ downwind of the Beijing urban center, based on comparison with comparative data for $\mathrm{Au}-$ gust 2006-2007. The mean daytime mixing ratio of $\mathrm{O}_{3}$ was reduced by about $15 \mathrm{ppbv}$ in August 2008 from $65 \mathrm{ppbv}$ in August 2006-2007, while daytime $\mathrm{O}_{3}$ averaged only $45 \mathrm{ppbv}$ during the time period of the Olympics (4 August-24 August 2008). The decrease in $\mathrm{O}_{3}$ was most significant in the afternoon when in situ photochemical production of $\mathrm{O}_{3}$ is most active. The reduction in $\mathrm{O}_{3}$ was reflected not only in mean but also in peak concentrations.

In August 2008, the relative reductions in daytime mixing ratios of $\mathrm{SO}_{2}, \mathrm{CO}$, and $\mathrm{NO}_{\mathrm{y}}$ observed at Miyun amounted to $61 \%, 25 \%$, and $21 \%$, respectively as compared to the same month a year earlier. Concentrations of the three species are positively correlated at Miyun, indicating that they originate from co-located sources. While there is no significant change 
in the $d \mathrm{CO} / d \mathrm{NO}_{\mathrm{y}}$ enhancement ratio from August 2007 to 2008 , the $d \mathrm{CO} / d \mathrm{SO}_{2}$ and $d \mathrm{NO}_{\mathrm{y}} / d \mathrm{SO}_{2}$ enhancement ratios in August 2008 are significantly larger than values for $\mathrm{Au}-$ gust 2007, suggesting that the relative reduction of $\mathrm{SO}_{2}$ emissions is much larger than that of $\mathrm{CO}$ and $\mathrm{NO}_{\mathrm{x}}$. Control strategies targeting the power sector reduced emissions of $\mathrm{SO}_{2}$ and NOx, but most effectively for the former, resulting in increases in the $\mathrm{NO}_{\mathrm{x}} / \mathrm{SO}_{2}, \mathrm{CO} / \mathrm{SO}_{2}$, and $\mathrm{CO} / \mathrm{NO}_{\mathrm{x}}$ ratios. Because of the strict ban placed on old, inefficient vehicles, the traffic restriction tended to decrease the $\mathrm{CO} / \mathrm{NO}_{\mathrm{x}}$ ratio, compensating for the effect of power sector emission control. The changes in the enhancement ratios, after excluding the impact of the variability of $\mathrm{SO}_{2}$ lifetime, indicate that the relative reductions in emissions of $\mathrm{SO}_{2}, \mathrm{CO}$, and $\mathrm{NO}_{\mathrm{x}}$ in $\mathrm{Au}-$ gust 2008 correspond to $60 \%, 32 \%$, and $36 \%$, respectively, as compared with the same month the year earlier. Our "topdown" estimate of the reductions is found to be consistent with the bottom-up estimate for $\mathrm{SO}_{2}$ but is lower for $\mathrm{CO}$ and $\mathrm{NO}_{\mathrm{x}}$. The combination of the top-down and bottom-up estimates on emissions of different species is used to define the Olympics emissions used to drive the model simulation.

The nested-grid GEOS-Chem model with $0.5^{\circ} \times 0.667^{\circ}$ horizontal resolution over China is found to reproduce well the day-to-day variations in $\mathrm{O}_{3}, \mathrm{CO}, \mathrm{NO}_{\mathrm{y}}$, and $\mathrm{SO}_{2}$ observed at Miyun but significantly overestimates mixing ratios derived using the standard 2007 emissions. Adoption of the Olympics emission reconstruction in the model leads not only to significant reductions in model biases but also to improvements in the temporal correlations between model and observations. Analysis of meteorological conditions observed at Miyun for the three years covered by the present observations and interpretation of the observations using the model both suggest that the reduction in emissions of ozone precursors associated with the Olympic Games made a significant contribution to the observed decrease in $\mathrm{O}_{3}$ during August 2008, accounting for $80 \%$ of the $\mathrm{O}_{3}$ reduction for the month as a whole and $45 \%$ during the Olympics Period (824 August). Because of the controls on regional emissions as well as the relatively long lifetime of $\mathrm{O}_{3}$, the model predicts that emission restrictions can affect $\mathrm{O}_{3}$ far beyond the Beijing urban area, resulting in boundary layer $\mathrm{O}_{3}$ reductions of $2-10$ ppbv over a large region of the North China Plain and Northeastern China.

Acknowledgements. This research was supported by the National Science Foundation, grant ATM-0635548, by the Harvard University Smeltzer Fund and by funds from an anonymous private foundation. Y. Wang and J. M. Hao are supported by the National Science Foundation of China, 20921140095.

Edited by: J. G. Murphy

\section{References}

Beirle, S., Platt, U., Wenig, M., and Wagner, T.: Weekly cycle of $\mathrm{NO}_{2}$ by GOME measurements: a signature of anthropogenic sources, Atmos. Chem. Phys., 3, 2225-2232, 2003, http://www.atmos-chem-phys.net/3/2225/2003/.

Bey, I., Jacob, D. J., Yantosca, R. M., Logan, J. A., Field, B., Fiore, A. M., Li,, Q., Liu, H., Mickley, L. J., and Schultz, M.: Global modeling of tropospheric chemistry with assimilated meteorology: Model description and evaluation, J. Geophys. Res., 106, 23073-23096, 2001.

Chen, D., Wang, Y., McElroy, M. B., He, K., Yantosca, R. M., and Le Sager, P.: Regional CO pollution and export in China simulated by the high-resolution nested-grid GEOS-Chem model, Atmos. Chem. Phys., 9, 3825-3839, 2009, http://www.atmos-chem-phys.net/9/3825/2009/.

Cheng, Y. F., Heintzenberg, J., Wehner, B., Wu, Z. J., Su, H., Hu, M., and Mao, J. T.: Traffic restrictions in Beijing during the Sino-African Summit 2006: aerosol size distribution and visibility compared to long-term in situ observations, Atmos. Chem. Phys., 8, 7583-7594, 2008, http://www.atmos-chem-phys.net/8/7583/2008/.

Chou, C. C.-K., Tsai, C.-Y., Shiu, C.-J., Liu, S. C., and Zhu, T.: Measurement of $\mathrm{NO}_{y}$ during Campaign of Air Quality Research in Beijing 2006 (CAREBeijing-2006): Implications for the ozone production efficiency of $\mathrm{NO}_{\mathrm{x}}$, J. Geophys. Res., 114, D00G01, doi:10.1029/2008JD010446, 2009.

Davis, J. M. and Speckman, P.: A model for predicting maximum and $8 \mathrm{~h}$ average ozone in Houston, Atmos. Environ., 33, 24872500, 1999.

Ding, A. J., Wang, T., Thouret, V., Cammas, J.-P., and Nédélec, P.: Tropospheric ozone climatology over Beijing: analysis of aircraft data from the MOZAIC program, Atmos. Chem. Phys. Discuss., 7, 9795-9828, 2007,

http://www.atmos-chem-phys-discuss.net/7/9795/2007/.

Elminir, H. K.: Dependence of urban air pollutants on meteorology, Sci. Total Environ., 350, 225-237, 2005.

Hao, J. M. and Wang, L. T.: Improving urban air quality in China: Beijing case study, J. Air Waste Manage., 55, 1298-1305, 2005.

Harley, R. A., Marr, L. C., Lehner, J. K., and Giddings, S. N.: Changes in motor vehicle emissions on diurnal to decadal time scales and effects on atmospheric composition, Environ. Sci. Technol., 39, 5356-5362, 2005.

Hirsch, R. M. and Gilroy, E. J.: Methods of fitting a straight line to data: Examples in water resources, Water Resour. Bull., 20, 705-711, 1984.

Lin, W., Xu, X., Zhang, X., and Tang, J.: Contributions of pollutants from North China Plain to surface ozone at the Shangdianzi GAW Station, Atmos. Chem. Phys., 8, 5889-5898, 2008, http://www.atmos-chem-phys.net/8/5889/2008/.

Murphy, J. G., Day, D. A., Cleary, P. A., Wooldridge, P. J., Millet, D. B., Goldstein, A. H., and Cohen, R. C.: The weekend effect within and downwind of Sacramento: Part 2, Observational evidence for chemical and dynamical contributions, Atmos. Chem. Phys. Discuss., 6, 11971-12019, 2006,

http://www.atmos-chem-phys-discuss.net/6/11971/2006/.

Murphy, J. G., Day, D. A., Cleary, P. A., Wooldridge, P. J., Millet, D. B., Goldstein, A. H., and Cohen, R. C.: The weekend effect within and downwind of Sacramento - Part 1: Observations of ozone, nitrogen oxides, and VOC reactivity, Atmos. Chem. 
Phys., 7, 5327-5339, 2007, http://www.atmos-chem-phys.net/7/5327/2007/.

NRC (National Research Council): Rethinking the ozone problem in urban and regional air pollution, National Academy Press, Washington, D.C., 1991.

Ohara, T., Akimoto, H., Kurokawa, J., Horii, N., Yamaji, K., Yan, X., and Hayasaka, T.: An Asian emission inventory of anthropogenic emission sources for the period 1980-2020, Atmos. Chem. Phys., 7, 4419-4444, 2007, http://www.atmos-chem-phys.net/7/4419/2007/.

Platnick, S., King, M. D., Ackerman, S. A., Menzel, W. P., Baum, B. A., Riedi, J. C., and Frey, R. A.: The MODIS cloud products: Algorithms and examples from Terra, IEEE Trans. Geosci. Remote Sens., 41(2), 459-473, 2003.

Sillman, S., Logan, J. A., and Wofsy, S. C.: The sensitivity of ozone to nitrogen oxides and hydrocarbons in regional ozone episodes, J. Geophys. Res., 95, 1837-1852, 1990.

Sillman, S.: The Use of NOy, $\mathrm{H}_{2} \mathrm{O}_{2}$, and $\mathrm{HNO}_{3}$ as indicators for ozone- $\mathrm{NO}_{\mathrm{x}}$-hydrocarbon sensitivity in urban locations, J. Geophys. Res., 100, 14175-14188, 1995.

Streets, D. G., Fu, J. H. S., Jang, C. J., Hao, J. M., He, K. B., Tang, X. Y., Zhang, Y. H., Wang, Z. F., Li, Z. P., Zhang, Q., Wang, L. T., Wang, B. Y., and Yu, C. Air quality during the 2008 Beijing Olympic Games, Atmos. Environ., 41(3), 480-492, 2007.

Trainer, M., Parrish, D. D., Goldan, P. D., Roberts, J., and Fehsenfeld, F.C.: Review of observation-based analysis of the regional factors influencing ozone concentrations, Atmos. Environ., 34, 2045-2061, 2000.

Wang, L. T., Hao, J. M., He, K. B., Wang, S. X., Li, J. H., Zhang, Q., Streets, D. G., Fu, J. S., Jang, C. J., Takekawa, H., and Chatani, S.: A modeling study of coarse particulate matter pollution in Beijing: Regional source contributions and control implications for the 2008 summer Olympics, J. Air Waste Manage., 58(8), 1057-1069, 2008a.
Wang, T., Ding, A., Gao, J., and Wu, W. S.: Strong ozone production in urban plumes from Beijing, China, Geophys. Res. Lett., 33, L21806, doi:10.1029/2006GL027689, 2006.

Wang, Y. X., McElroy, M. B., Jacob, D. J., and Yantosca, R. M.: A nested grid formulation for chemical transport over Asia: Applications to CO, J. Geophys. Res., 109, D22307, doi:10.1029/2004JD005237, 2004a.

Wang, Y. X., McElroy, M. B., Wang, T., and Palmer, P. I.: Asian emissions of $\mathrm{CO}$ and $\mathrm{NO}_{\mathrm{X}}$ : Constraints from aircraft and Chinese station data, J. Geophys. Res., 109, D24304, doi:10.1029/2004JD005250, 2004b.

Wang, Y., McElroy, M. B., Munger, J. W., Hao, J., Ma, H., Nielsen, C. P., and Chen, Y.: Variations of $\mathrm{O}_{3}$ and $\mathrm{CO}$ in summertime at a rural site near Beijing, Atmos. Chem. Phys., 8, 6355-6363, 2008 , http://www.atmos-chem-phys.net/8/6355/2008/.

Wild, O., Zhu, X., Prather, M. J., and Fast, J.: Accurate simulation of in- and below cloud photolysis in tropospheric chemical models, J. Atmos. Chem., 37, 245-282, 2000.

Zhang, Q., Streets, D. G., He, K., et al.: $\mathrm{NO}_{\mathrm{x}}$ emission trends for China, 1995-2004: The view from the ground and the view from space, J. Geophys. Res., D22306, doi:10.1029/2007JD008684, 2007.

Zhang, Q., Streets, D. G., Carmichael, G. R., He, K., Huo, H., Kannari, A., Klimont, Z., Park, I., Reddy, S., Fu, J. S., Chen, D., Duan, L., Lei, Y., Wang, L., and Yao, Z.: Asian emissions in 2006 for the NASA INTEX-B mission, Atmos. Chem. Phys. Discuss., 9, 4081-4139, 2009, http://www.atmos-chem-phys-discuss.net/9/4081/2009/.

Zhao, Y., Wang, S. X., Duan, L., et al.: Primary air pollutant emissions of coal-fired power plants in China: Current status and future prediction, Atmos. Environ., 42, 8442-8452, 2008. 